\title{
FAKTOR-FAKTOR PENDORONG KONSUMEN SURABAYA MEMBELI MAKANAN DAN MINUMAN MELALUI APLIKASI GOFOOD DAN GRABFOOD
}

\author{
Marcella Puspita ${ }^{1}$, Adriana Aprilia ${ }^{2 *}$ \\ ${ }^{1,2}$ Program Manajemen Perhotelan, Program Studi, Manajemen, Fakultas Bisnis dan Ekonomi \\ Universitas Kristen Petra. Jl. Siwalankerto 121-131, Surabaya \\ * Penulis korespondensi; Email: aprilia@petra.ac.id
}

\begin{abstract}
Abstrak
Penelitian ini bertujuan untuk mengetahui faktor-faktor yang mendorong konsumen Surabaya membeli makanan dan minuman melalui aplikasi GoFood dan Grabfood. Kuesioner telah disebarkan kepada 351 responden dan data dianalisis dengan menggunakan analisa faktor dengan SPSS for windows 16.0. Hasil analisa ini menunjukkan 8 faktor baru yang mendorong konsumen membeli makanan dan minuman melalui aplikasi yaitu kualitas layanan dan aplikasi, variasi, gaya hidup, efektivitas dan efiesiensi, kondisional, sosial, preferensi dan individu.
\end{abstract}

Kata kunci: GoFood, GrabFood, analisa faktor, pembelian makanan online.

\begin{abstract}
This research was conducted to find what factors that contribute to customer purchase online decision through GoFood and Grabfood online transportation service in buying food and beverage. Questionnaires were distributed to 351 respondents and the data was analyzed using factor analysis with SPSS for windows 16.0. The research showed 8 new factors that were formed. The new factors were service quality ang application, variance, lifestyle, effectiveness and efficient, conditional, social, preference and individual.
\end{abstract}

Keywords: GoFood, GrabFood, factor analysis, food online purchasing.

\section{PENDAHULUAN}

Saat ini belanja online merupakan suatu hal sebagai pola pembelian baru yang telah menjadi kebiasaan bagi sebagian orang. Belanja online adalah kegiatan belanja yang dilakukan melalui media atau perantara online, seperti situs-situs web, e-commerce, media sosial, maupun m-commerce (Harahap dan Amanah, 2018). Banyak orang yang menjadikan belanja online sebagai suatu kebiasaan, baik untuk membeli kebutuhan sehari-hari hingga memenuhi gaya hidup. Belanja online dinilai efisien, praktis, aman, dan harga produk yang lebih murah dibanding di toko offline.

Menurut Suhari (2008), belanja online juga merupakan efisiensi dalam pencarian (waktu, tenaga, dan biaya). Masyarakat dapat dengan mudah membandingkan harga suatu barang di setiap toko yang tersedia. Selain itu, barang yang akan didapat juga memiliki kualitas yang sama dengan barang yang dijual di toko offline, tetapi dengan harga yang lebih murah. Pada umumnya konsumen yang membeli secara online didominasi oleh pembeli yang berusia 18-40 tahun dan sudah terbuka terhadap teknologi media sosial (Veronika, 2013).
Menurut penelitian yang dilakukan oleh Santoso dan Prayitno (2011), perkembangan e-commerce yang bertumbuh pesat di Indonesia dapat dilihat dari beralihnya fungsi jejaring sosial seperti website dan facebook yang awalnya hanya digunakan untuk membagikan kabar dan bersosialisasi menjadi salah satu wadah jual beli online. Kepala Badan Pusat Statistik (BPS), Suhariyanto melihat bahwa kini masyarakat cenderung membeli makanan melalui aplikasi digital daripada harus memasak sendiri/pergi membeli makanan secara langsung ke toko secara offline.

Seiring dengan perkembangan zaman dan teknologi, fenomena m-commerce mulai populer di kalangan warga Surabaya. Saat ini terdapat fenomena menarik dalam industri jasa layanan antar makanan secara online. Diawali dengan hadirnya dua mobile commerce berbasis online transportation service, yaitu Gojek dan Grab. Keduanya adalah m-commerce berbasis online transportation service atau lebih mudahnya disebut perusahan jasa ojek online terbesar di Indonesia. Gojek didirikan oleh Nadiem Anwar Makarim pada tahun 2010, sedangkan Grab mulai memasuki pasar Indonesia pada bulan Juni tahun 2014. Kedua perusahaan ini bersaing dalam mengembangkan fitur-fitur dan jenis pelayanan yang 
dimiliki. Salah satunya GoFood pada Gojek dan GrabFood pada Grab. Kedua jenis pelayanan tersebut adalah layanan untuk memesan makanan secara online, selanjutnya mitra ojek online yang akan mengantarkan makanan sampai pada tujuan.

Di beberapa kota besar, terutama Surabaya, GoFood dan GrabFood telah menjadi fenomena beberapa tahun terakhir ini. Menurut pengamatan penulis, sering sekali dijumpai mitra ojek online yang membelikan pesanan makanan dari konsumen di berbagai toko makanan atau minuman. Dengan hadirnya layanan ini, saat ini konsumen banyak membeli makanan atau minuman secara online. Terkait dengan fenomena tersebut, dilakukan survei awal terhadap 10 orang dan menunjukkan adanya 31 alasan yang mendorong konsumen di Surabaya membeli makanan dan minuman melalui aplikasi GoFood dan GrabFood, diantaranya seperti efisien, malas memasak, lebih murah daripada masak sendiri dan lain-lain.

Berdasarkan beberapa alasan tersebut, penulis akan mengonfirmasi faktor-faktor awal pada penelitian Dewi, Suthanaya dan Sujadi, 2019 yang dilakukan di kabupaten Badung. Awal mulanya terdapat 3 faktor yang memengaruhi konsumen menggunakan aplikasi transportasi online yaitu 1) faktor sosial yang terdiri dari budaya, kelas sosial, kelompok referensi, keluarga; 2) faktor personal terdiri dari faktor persepsi, pembelajaran, motif, kepribadian, sikap dan memori dan 3) faktor bauran pemasaran terdiri dari faktor produk, harga, promosi, distribusi, manusia dan proses. Hasil penelitian menunjukkan adanya 5 faktor baru yang mendorong konsumen menggunakan pelayanan GoRide pada Gojek di kabupaten Badung yaitu 1) faktor kualitas pelayanan dan aplikasi, 2) faktor individu, 3) faktor harga, 4) faktor sosial dan 5) faktor gaya hidup. Penelitian ini bertujuan untuk mengetahui faktor-faktor apa saja yang mendorong konsumen untuk melakukan pembelian makanan dan minuman secara online melalui aplikasi Grabfood dan Gofood.

\section{TINJAUAN PUSTAKA}

\section{Perilaku Belanja Online}

Perilaku pembelian online adalah proses konsumen dalam melakukan pembelian produk dan jasa melalui internet. Pembelian secara online telah menjadi alternatif untuk melakukan pembelian barang atau jasa (Harahap dan Amanah ,2018). Menurut Kim, Ferrin \& Rao (2008) terdapat beberapa faktor yang memengaruhi perilaku pembelian online konsumen:

1. Persepsi manfaat

Persepsi manfaat merupakan keyakinan konsumen tentang belanja online untuk mendapatkan sesuatu yang lebih baik pada transaksi online. Selain itu manfaatnya adalah penghematan waktu, karena bagi konsumen yang sibuk dengan pekerjaanya sehingga tidak dapat belanja di tempat, maka konsumen dapat secara langsung belanja melalui website online.

2. Persepsi risiko

Risiko yang dirasakan konsumen akan memengaruhi keputusan pembelian online, karena bagi konsumen yang melakukan transaksi online dapat enggan membeli di web karena risiko yang lebih besar jika dibandingkan dengan pembelian secara langsung di tempat.

\section{Faktor yang Memengaruhi Proses Pembelian Online}

Sedangkan, faktor-faktor yang memengaruhi konsumen dalam melakukan pembelian melalui aplikasi tranportasi online dipengaruhi oleh 3 faktor (Dewi, Suthanaya, dan Sujadi (2019):

1. Faktor sosial, merupakan faktor yang berasal dari luar individu. Biasanya faktor ini berasal dari lingkungan sekitar, seperti dari budaya, kelas sosial, kelompok referensi, dan keluarga.

- Faktor budaya

Budaya merupakan penentu keinginan dan perilaku paling dasar. Budaya menunjukkan karakteristik tertentu yang membatasinya dalam bertindak yang menunjukkan identitasnya masing-masing, seperti: ras, etnik, suku, agama, dan wilayah geografis yang membentuk kebutuhan dan keinginan konsumen yang berbeda-beda (Kotler dan Armstrong, 2016).

- Faktor kelas sosial

Kelas sosial adalah kelas sosial yang menjadi tempat individu berinteraksi satu sama lain karena adanya kesamaan nilai, ketertarikan, dan perilaku antar individu. Kelas sosial seseorang merujuk pada penggunaan produk dan merek yang berbeda-beda di setiap kelas sosial, misalnya saja seperti pakaian, peralatan rumah tangga dan aktifitas sehari-hari (Schiffman dan Wisenblit, 2015).

- Faktor kelompok referensi

Kelompok referensi adalah semua kelompok yang memiliki pengaruh secara langsung maupun tidak langsung pada sikap atau perilaku seseorang. Kelompok referensi bisa berasal dari teman sebaya, lingkungan kerja, sekolah, maupun tempat seseorang bergaul (Kotler dan Keller, 2006).

- Faktor keluarga

Anggota keluarga sangat memengaruhi perilaku pembelian konsumen terhadap produk yang ingin dibeli. Keluarga merupakan tempat seseorang memperoleh nilai-nilai atau pandangan-pandangan pertama dalam hidup (Kotler dan Armstrong, 2016). 
2. Faktor personal, merupakan faktor yang berasal dari diri sendiri atau individu seperti dari segi persepsi, pembelajaran, motif, kepribadian, sikap dan memori.

- Faktor persepsi

Persepsi adalah proses dimana individu memilih, mengatur dan mengartikan informasi yang diperoleh untuk menciptakan suatu gambaran mengenai apa yang akan didapat dari suatu barang/jasa. Konsumen yang bertindak ingin membeli suatu produk akan dipengaruhi oleh persepsinya sendiri tentang kondisi barang atau jasa tersebut (Kotler dan Armstrong, 2016).

- Faktor pembelajaran

Proses pembelajaran meliputi perubahanperubahan pada diri seseorang yang berkembang dari pengalaman. Pembelajaran diartikan sebagai proses dimana seseorang mendapatkan suatu pengetahuan dan pengalaman yang diterapkan untuk perilaku selanjutnya (Kotler dan Armstrong, 2016).

- Faktor motif

Motif berasal dari motivasi individu dalam memenuhi suatu kebutuhan. Motivasi adalah kegiatan dalam diri seseorang yang mendorong keinginan individu untuk melakukan kegiatankegiatan tertentu untuk mencapai suatu tujuan. Konsumen dengan kebutuhan mendesak biasanya akan lebih cepat menentukan pembelian suatu produk atau jasa dibandingkan dengan keinginan saja (Kotler dan Armstrong, 2016).

- Faktor kepribadian Kepribadian didefinisikan sebagai karakteristik psikologis yang membedakan seseorang dengan kelompok. Kepribadian seseorang sangat berpengaruh dalam pengambilan keputusan pembelian (Kotler dan Armstrong, 2016).

- Faktor sikap

Sikap adalah menggambarkan evaluasi, perasaan dan kecenderungan seseorang yang relatif konsisten tehadap suatu produk. Sikap seseorang terhadap produk atau merek memengaruhi tindakan membeli atau menggunakan produk atau merek tersebut (Kotler dan Armstrong, 2016).

- Faktor memori

Memori adalah kemampuan seseorang dalam mengingat perubahan-perubahan yang terjadi berdasarkan pengetahuan dan kepercayaan yang terdapat dalam ingatan seseorang. Jika ingatan yang dimiliki terhadap produk/jasa baik, maka keputusan untuk membeli lebih cepat diambil (Amirullah, 2002).

3. Faktor bauran pemasaran, merupakan faktor yang berasal dari variabel-variabel terkendali yang dapat digunakan pemasar untuk memengaruhi tanggapan konsumen.

\section{- Faktor produk}

Produk adalah kegiatan mengombinasikan barang dan jasa yang ditawarkan perusahaan kepada konsumen. Kegiatan ini sangat penting, dikarenakan situasi dan kondisi pasar yang dinamis. Maka dari itu, perusahaan dituntut untuk menghasilkan dan menawarkan produk yang memiliki nilai yang tinggi dan sesuai dengan selera konsumen (Kotler dan Armstrong, 2016).

- Faktor harga

Harga adalah jumlah uang yang harus dibayar oleh konsumen untuk mendapatkan suatu produk atau jasa. Harga produk yang diberikan oleh suatu perusahaan harus sesuai dengan layanan/produk yang diberikan (Kotler dan Armstrong, 2016).

- Faktor promosi

Promosi yaitu kegiatan yang mengomunikasikan keunggulan produk dan membujuk konsumen untuk membelinya. Promosi dapat dilakukan dengan berbagai cara, misalnya: dengan memasang iklan pada spanduk dan papan iklan di jalan raya, pemberian diskon, pemberian sistem poin ketika melakukan suatu transaksi, dan lain-lain (Kotler dan Armstrong, 2016).

- Faktor distribusi

Distribusi berfokus pada bagaimana langkahlangkah untuk mengantarkan barang/jasa kepada konsumen dan mempersiapkan segala solusi untuk permasalahan yang mungkin terjadi dalam proses pemenuhan pesanan konsumen (Wilson dan Giligan, 2005)

- Faktor manusia

Manusia merupakan aset utama dalam suatu perusahaan. Kebutuhan konsumen terhadap karyawan berkinerja tinggi akan menyebabkan konsumen puas dan loyal terhadap perusahaan tersebut (Lupiyoadi dan Hamdani, 2006)

- Faktor proses

Layanan jasa ataupun kualitas produk sangat bergantung pada proses penyampaian jasa kepada konsumen. Untuk menjamin mutu layanan, seluruh karyawan perusahaan harus menjalankan kegiatan operasional sesuai dengan sistem dan prosedur yang sudah terstandarisasi (Zeithaml, Bitner, dan Gremler, 2009). 


\section{Tipe pengguna atau pembeli online}

Ada 4 tipe profil pengguna atau pembeli online yang dijelaskan oleh Harahap dan Amanah (2018):

- Innovator

Tipe innovator adalah konsumen yang memiliki pendapatan yang tinggi dan memiliki perangkat online lebih dari satu. Saat konsumen hendak membeli produk, konsumen memperhatikan garansi dari produk yang dibeli dan saat pembayaran konsumen lebih menyukai menggunakan internet banking. Tipe innovator lebih memilih menggunakan aplikasi smartphone untuk berbelanja daripada menggunakan situs web.

- Early Adopter

Tipe pengguna belanja online di Indonesia ialah Early Adopter. Tipe ini mencerminkan konsumen yang cenderung memiliki pendapatan rendah dan memiliki perangkat online lebih dari satu, senang melakukan transaksi online menggunakan internet banking atau transfer melalui Automated Teller Machine atau ATM. Selain itu tipe ini adalah konsumen yang menyukai berburu diskon di tokotoko online.

- Gaptek (Gap-Tech)

Merupakan tipe yang disebut dengan istilah Gaptek atau Gap-Tech, maksudnya adalah orang-orang yang kurang mengerti terhadap teknologi. Tipe ini adalah konsumen cenderung memiliki pendapatan tinggi, memiliki 1 perangkat online/elektronik. Saat mencari informasi lebih memilih untuk mengakses menggunakan situs web daripada aplikasi dan saat pembayaran lebih memilih untuk menggunakan metode transfer ATM. Tipe gaptek sama dengan tipe early adopter bahwa konsumen suka memburu diskon pada toko-toko online.

\section{- Late Bloomers}

Tipe Late Bloomers ini konsumen cenderung memiliki pendapatan rendah, memiliki 1 perangkat online, dan saat membeli produk online konsumen dapat mencarinya dari aplikasi. Konsumen tidak terlalu mementingkan toko online, asalkan barang yang hendak dibeli tersedia dan konsumen akan langsung membelinya. Diketahui pula, konsumen yang masuk tipe late bloomers adalah konsumen yang lebih memilih metode COD (cash on delivery) yang artinya membayar langsung produk yang dibeli.

\section{Proses Pengambilan Keputusan Pembelian}

Menurut Mowen dan Minor (2001) serta Peter dan Olson (2008), proses pembelian secara online maupun konvensional secara umum dapat dikelompokan ke dalam beberapa tahap sebagai berikut:

1. Mengenali permasalahan

Sebelum masuk ke tahap-tahap lainnya, terutama dalam proses pengambilan alternatif, maka konsumen akan mengenali masalah yang terjadi dan harus diselesaikan.

2. Mencari alternatif solusi

Mencari informasi yang relevan untuk menemukan solusi potensial dari lingkungan eksternal (misalnya: teman, keluarga, guru, internet, dan lain-lain).

3. Mengevaluasi masing-masing alternatif solusi

Seseorang akan menggunakan kemampuan dan pengetahuan yang dimilikinya untuk membuat suatu keputusan. Sifat evaluasi dan nilai dari masingmasing ini akan dipersepsikan secara personal.

4. Pembelian

Melakukan pembelian terhadap alternatif yang dipilih, berserta segala konsekuensinya.

5. Pemanfaatan produk dan evaluasi ulang terhadap alternatif yang dipilih

Pada tahap ini, proses mengacu pada konsumsi produk, penempatan produk, dan kepuasan atau ketidakpuasan konsumen terhadap suatu produk. Ketika terjadi proses konsumsi, konsumen akan menilai produk tersebut. Biasanya konsumen akan membandingkan kualitas dan performa suatu produk dengan ekspektasi yang dimiliki.

\section{Kerangka Pemikiran}

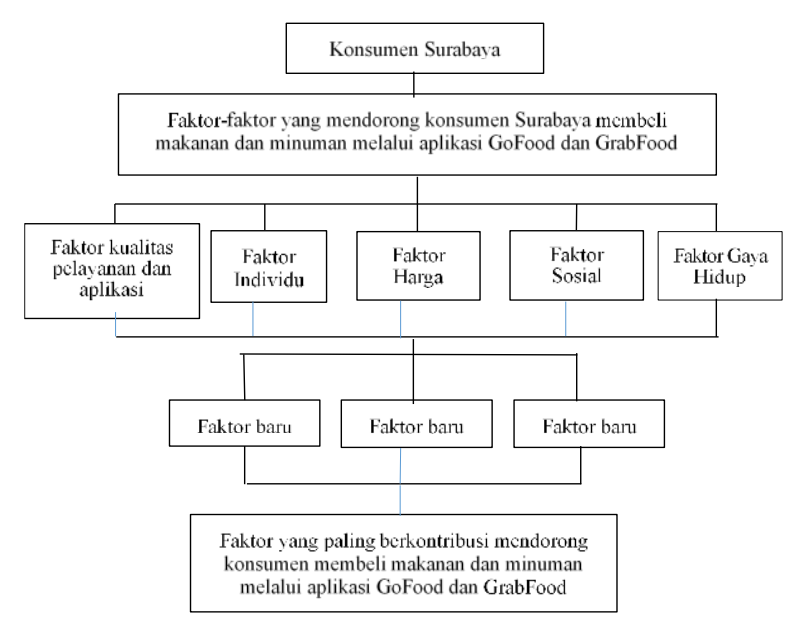

Gambar 1. Kerangka Pemikiran (Sumber: Adaptasi penelitian Dewi, Suthanaya, dan Sujadi 2019)

Dalam penelitian ini, penulis akan mengonfirmasi indikator-indikator yang ada berdasar 5 faktor yang didapat melalui penelitian yang dilakukan oleh Dewi, Suthanaya, dan Sujadi (2019), sehingga diharapkan akan didapat faktor-faktor baru yang relevan dengan keadaan di Surabaya. 


\section{METODE PENELITIAN}

Pengambilan data untuk penelitian ini adalah dengan survei. Populasi penelitian ini adalah semua konsumen Surabaya. Teknik pengambilan sampel yang digunakan adalah non-probability sampling jenis judgemental sampling. Sampel yang dilibatkan sebanyak 351 responden dengan kriteria: warga Surabaya, berusia di atas 17 tahun, dan pernah melakukan pembelian makanan dan/atau minuman melalui aplikasi GoFood dan GrabFood.

Sebelum menyusun kuesioner, dilakukan survei awal dengan penyebaran kuesioner melalui google form. Pada survei awal responden diberikan pertanyaan tertutup yaitu "aplikasi layanan transportasi online apa yang sering digunakan untuk membeli makanan secara online? " dan "alasan apa yang mendorong konsumen Surabaya untuk melakukan pembelian makanan atau minuman secara online?". Berikut ada 31 alasan yang diberikan responden atas pertanyaan di atas:

1. Efisien

2. Malas/tidak bisa memasak

3. Jadwal aktivitas yang padat

4. Lebih murah daripada masak sendiri

5. Ongkos kirim setimpal dengan jarak pengiriman dan pelayanan yang diberikan

6. Banyak promo makanan melalui aplikasi Gofood dan Grabfood sehingga harga makanan lebih murah

7. Adanya sistem perolehan poin setiap bertransaksi

8. Banyak pilihan mitra pedagang (merchant) makanan/minuman

9. Banyak pilihan menu makanan/minuman

10. Banyak yang memakai fitur layanan pengiriman makanan dalam aplikasi transportasi online

11. Aplikasi mudah untuk digunakan

12. Pengiriman lebih cepat dibanding dengan layanan pesan antar konvensional

13. Bisa membayar melalui dompet digital (misalnya: GO-PAY dan OVO)

14. Jumlah mitra pengemudi banyak dan tersebar di mana saja

15. Aplikasi aman, terpercaya, dan dapat diakses di mana saja

16. Pelayanan yang memuaskan

17. Mitra pengemudi cepat tanggap dan ramah

18. Tidak perlu bingung memilih restoran

19. Bosan dengan makanan yang ada di sekitar tempat tinggal

20. Tidak memiliki kendaraan

21. Rekomendasi teman/rekan kerja

22. Rekomendasi keluarga

23. Pelayanan yang tidak mengenal cuaca (misalnya: tetap mengantar makanan meskipun hujan deras)
24. Menghemat ongkos (tidak mengeluarkan biaya untuk bensin dan kontribusi parkir)

25. Adanya fitur untuk melakukan pemesanan ulang (re-order) menu yang pernah dipesan sebelumnya

26. Kondisi yang tidak memungkinkan untuk keluar dari tempat tinggal, misalnya: cuaca buruk

27. GoFood/GrabFood merupakan suatu kebutuhan

28. Menggunakan layanan Gofood/GrabFood karena tren

29. Menggunakan layanan Gofood/GrabFood karena gaya hidup

30. Menggunakan layanan karena melihat iklan (melalui youtube, papan iklan, instagram dan lain-lain)

31. Lebih nyaman memilih menu makan di rumah karena tidak diburu waktu untuk memilih

\section{HASIL PENELITIAN DAN PEMBAHASAN}

Analisa data merupakan tahapan yang penting untuk mencapai tujuan penelitian ini yaitu untuk mengetahui faktor-faktor baru yang mendorong konsumen Surabaya membeli makanan dan minuman melalui aplikasi GoFood dan GrabFood. Tahap pengujian validitas dan reliabilitas dilakukan sebelum pengolahan data untuk memastikan bahwa butir-butir indikator mampu mengukur apa yang harus diukur.

Uji validitas digunakan untuk mengetahui kelayakan butir-butir pernyataan dalam mendefinisikan suatu variabel (Sujarweni dan Endrayanto, 2012). Teknik yang akan digunakan untuk menguji validitas adalah teknik konten (content validity) dan teknik rupa (face validity). Dalam teknik konten, penulis menggunakan aplikasi SPSS 16.0 untuk menghitung korelasi pearson ( $r$ hitung). Jika ditemukan $r$ hitung $\geq r$ tabel maka dikatakan valid. Nilai rujukan yang digunakan dalam penelitian ini adalah 0,361. Teknik rupa digunakan untuk meyakinkan bahwa pernyataanpernyataan tersebut masuk akal dan benar, biasanya dilakukan dengan meminta pendapat ahli-ahli yang bersangkutan (Martono, 2016; Jogiyanto, 2008). Uji validitas dilakukan terhadap 30 responden dengan sisnifikansi 5\%.

Setelah dilakukan uji validitas terhadap 30 responden, semua indikator dinyatakan valid karena $\mathrm{r}_{\text {hitung }}$ lebih besar daripada $\mathrm{r}_{\text {tabel }}$ yaitu 0,361 . Khusus variabel $X_{1}$ dan $X_{13}$, penulis menggunakan metode pengujian validitas dengan teknik rupa dikarenakan menurut penulis indikator tersebut merupakan indikator yang penting. Uji validitas untuk 2 indikator tersebut memiliki $r_{\text {hitung }}$ yang lebih kecil dari $r_{\text {tabel }}$ sehingga diputuskan untuk menggunakan uji validitas dengan teknik rupa karena pada uji validitas konten pertama variabel $X_{1}$ dan $X_{13}$ dinyatakan tidak valid. 
Selanjutnya dilakukan uji reliabilitas dengan merujuk pada nilai cronbach's alpha. Jika nilai koefisien Cronbach's Alpha $(\alpha)$ atau koefisien yang diperoleh $\geq 0,60$ maka kuesioner dapat dikatakan reliable (Ghozali, 2012). Hasil uji reliabilitas menunjukkan bahwa semua variabel mempunyai nilai cronbach's alpha > 0,6 sehingga dapat dikatakan reliabel yang berarti jika dilakukan pengukuran di lain waktu, hasilnya akan sama (Hair, Black, Babin, dan Anderson, 2010).

\section{Analisa Profil Responden}

Total responden pada penelitian ini yaitu 351 orang, mayoritas adalah perempuan yaitu sebanyak 237 orang $(67,5 \%)$, sedangkan responden laki-laki sebanyak 114 orang $(32,5 \%)$. Usisa didominasi kelompok umur 17 - 25 tahun sebanyak 239 orang $(68,1 \%)$. Untuk tingkat pendidikan responden mayoritas adalah S1 sebanyak 171 orang $(48,7 \%)$. Pekerjaan responden didominasi mahasiswa/pelajar sebanyak 171 orang $(48,7 \%)$. Kawasan tempat tinggal ada 2 kawasan yang mendominasi yaitu Surabaya Barat dan Surabaya Selatan masing-masing sebanyak 107 orang (30,5\%). Pendapatan responden didominasi kelompok pendapatan < Rp. 2.000 .000 sebanyak 123 orang (35\%). Pengeluaran per transaksi mayoritas pada rentang Rp.50.001 - Rp. 100.000 sebanyak 179 orang (51\%). Asal informasi mengetahui Grab/Gojek sebagian besar mengetahui dari media sosial sebanyak 264 orang $(75,2 \%)$. Frekuensi pembelian makanan secara online dalam 1 minggu didominasi 1- 2 kali sebanyak 174 orang $(49,6 \%)$.

\section{Analisa Deskriptif}

Berdasarkan hasil analisa mean atau nilai ratarata jawaban responden, indikator dengan tingkat persetujuan paling tinggi adalah banyak promo makanan melalui aplikasi GoFood dan GrabFood sehingga harga makanan lebih murah (variabel X6) dengan nilai rata-rata 4,42. Sedangkan variabel yang tingkat persetujuannya rendah adalah variabel X28 yaitu menggunakan layanan Gofood atau Grabfood karena tren dengan nilai rata-rata 2,56.

\section{Analisa Faktor}

Analisa faktor bertujuan untuk menyederhanakan beberapa variabel menjadi faktor yang lebih kecil jumlahnya dengan menggabungkan beberapa variabel menjadi satu faktor, sehingga terbentuk faktor-faktor yang dominan. Dalam penelitian ini, terdapat 31 variabel yang dapat direduksi menjadi beberapa faktor. Tahap-tahap dalam analisa faktor adalah sebagai berikut:

KMO dan Barlett's Test - Sampel dikatakan mencukupi untuk digunakan dalam analisa faktor jika Kaiser Meyer Olkin of Sampling Adequacy lebih besar dari 0,5 dan hasil menunjukkan 0,876 sehingga sampel layak untuk diproses lebih lanjut. Untuk uji Barlett's Test of Sphericity digunakan untuk menguji bahwa variabel-variabel yang ada tidak saling berkolerasi dalam satu populasi. Hasil uji ini yaitu 3,870 dengan probabilitas kesalahan (tingkat signifikansi 0,000), maka tidak adanya saling kolerasi antarvariabel, sehingga analisa faktor dapat dilakukan.

Anti Image Matrices -- Nilai MSA dari semua variabel menunjukkan $>0,5$ dengan demikian penelitian ini dapat diproses lebih lanjut, sebaliknya apabila nilai MSA < 0,5 maka harus dikeluarkan dari tabel. Selanjutnya menguji variance explained untuk melihat sejumlah variabel yang berasosiasi dengan setiap faktor. Faktor yang mempunyai eigen value 1 akan dimasukan di dalam tabel, sebaliknya jika nilai kurang dari 1 tidak akan dimasukan ke dalam tabel. Berikut merupakan total variance explained dari 31 variabel;

Tabel 1. Variance Explained

\begin{tabular}{|c|c|c|c|c|c|c|c|c|c|}
\hline \multirow{2}{*}{ Faktor } & \multicolumn{3}{|c|}{ Initial Eigenvalues } & \multicolumn{3}{|c|}{$\begin{array}{c}\text { Extraction Sums of Squared } \\
\text { Loadings } \\
\end{array}$} & \multicolumn{3}{|c|}{$\begin{array}{c}\text { Rotation Sums of Squared } \\
\text { Loadings } \\
\end{array}$} \\
\hline & Total & $\begin{array}{c}\% \text { of } \\
\text { Variance }\end{array}$ & $\begin{array}{c}\text { Cumulative } \\
\%\end{array}$ & Total & $\begin{array}{c}\% \text { of } \\
\text { Variance }\end{array}$ & $\begin{array}{c}\text { Cumulative } \\
\%\end{array}$ & Total & $\begin{array}{c}\% \text { of } \\
\text { Variance }\end{array}$ & Cumulative \% \\
\hline $\mathrm{X} 1$ & 8.082 & 26.070 & 26.070 & 8.082 & 26.070 & 26.070 & 3.672 & 11.846 & 11.846 \\
\hline $\mathrm{X} 2$ & 2.428 & 7.833 & 33.903 & 2.428 & 7.833 & 33.903 & 2.991 & 9.649 & 21.495 \\
\hline $\mathrm{X} 3$ & 1.762 & 5.683 & 39.586 & 1.762 & 5.683 & 39.586 & 2.599 & 8.384 & 29.878 \\
\hline $\mathrm{X} 4$ & 1.544 & 4.982 & 44.568 & 1.544 & 4.982 & 44.568 & 2.212 & 7.136 & 37.015 \\
\hline $\mathrm{X} 5$ & 1.444 & 4.658 & 49.226 & 1.444 & 4.658 & 49.226 & 2.093 & 6.750 & 43.765 \\
\hline X6 & 1.210 & 3.904 & 53.131 & 1.210 & 3.904 & 53.131 & 2.016 & 6.502 & 50.267 \\
\hline $\mathrm{X} 7$ & 1.130 & 3.644 & 56.774 & 1.130 & 3.644 & 56.774 & 1.688 & 5.446 & 55.713 \\
\hline $\mathrm{X} 8$ & 1.029 & 3.321 & 60.095 & 1.029 & 3.321 & 60.095 & 1.358 & 4.382 & 60.095 \\
\hline
\end{tabular}


Merujuk pada hasil tabel 1 bahwa variabel yang memiliki nilai eigen value $>1$ merupakan faktor-faktor baru yang terbentuk. Dengan ini terdapat 8 faktor baru yang terbentuk. Apabila terdapat eigen value $<1$ maka tidak bisa dipakai di dalam tabel. Total kumulatif dari faktor-faktor yang diekstraksi adalah sebesar 60,095\%. Angka tersebut menunjukkan bahwa penelitian ini mampu menjelaskan faktor-faktor yang mendorong konsumen Surabaya membeli makanan dan minuman melalui aplikasi GoFood dan GrabFood sebesar $60,095 \%$.

Communalities - pada analisa ini menunjukkan ekstraksi 8 faktor baru yaitu pada variabel X29 memiliki nilai yang paling tinggi yaitu sebesar 0,755 . Hal tersebut menunjukkan bahwa variabel "Menggunakan layanan Gofood /Grabfood karena gaya hidup" memberikan kontribusi sebesar 75,5\% untuk menjelaskan faktor baru yang terbentuk. Sedangkan, nilai ekstraksi yang terendah adalah variabel X31 sebesar 0,309. Hal ini menunjukkan bahwa variabel "Lebih nyaman memilih menu makanan di rumah karena tidak diburu waktu" memberikan kontribusi sebesar 30,9\% terhadap subfaktor baru yang terbentuk.

Component Matrix-menjelaskan seberapa besar kontribusi dari masing-masing variabel terhadap 8 faktor baru yang telah diekstrak. Selanjutnya dilakukan Rotated Component Matrix untuk menentukan masuknya suatu variabel ke dalam faktor yang baru maka diperlukan rotasi varimax. Hasil rotated component matrix didapatkan dari component matrix. Berikut hasil rotasi terlihat pada tabel 2 .

Untuk menentukan variabel mana yang dimasukkan ke dalam faktor baru maka dapat dilihat dari tabel rotated component matrix mencari nilai faktor terbesar dari masing-masing variabel setelah matriks dirotasi. Berikut merupakan faktor baru yang terbentuk:

a. Faktor 1: Kualitas Layanan dan Aplikasi

Faktor ini dibentuk oleh variabel-variabel sebagai berikut: aplikasi mudah untuk digunakan (X11), pengiriman lebih cepat dibanding dengan pesan antar konvensional/layanan pesan antar yang disediakan oleh pihak restoran (X12), bisa membayar

Tabel 2. Rotated Component Matrix

\begin{tabular}{|c|c|c|c|c|c|c|c|c|}
\hline & \multicolumn{8}{|c|}{ Komponen (Faktor) } \\
\hline & 1 & 2 & 3 & 4 & 5 & 6 & 7 & 8 \\
\hline $\mathrm{X} 1$ & 0.221 & 0.374 & 0.012 & 0.375 & 0.160 & -0.130 & 0.143 & 0.310 \\
\hline $\mathrm{X} 2$ & 0.045 & 0.106 & 0.171 & 0.225 & -0.021 & 0.009 & 0.063 & 0.703 \\
\hline $\mathrm{X} 3$ & 0.350 & 0.004 & 0.002 & 0.048 & 0.156 & 0.035 & 0.342 & 0.441 \\
\hline $\mathrm{X} 4$ & -0.030 & -0.082 & 0.261 & 0.647 & 0.012 & 0.135 & 0.220 & 0.181 \\
\hline $\mathrm{X} 5$ & 0.158 & 0.008 & 0.100 & 0.705 & 0.064 & 0.027 & 0.061 & 0.060 \\
\hline X6 & 0.269 & 0.330 & -0.018 & 0.604 & 0.062 & 0.024 & -0.142 & -0.041 \\
\hline $\mathrm{X} 7$ & 0.161 & 0.676 & 0.110 & 0.001 & -0.084 & 0.276 & -0.092 & 0.009 \\
\hline $\mathrm{X} 8$ & 0.211 & 0.783 & 0.125 & 0.099 & 0.140 & -0.038 & 0.180 & 0.049 \\
\hline $\mathrm{X} 9$ & 0.160 & 0.735 & 0.031 & 0.087 & 0.177 & -0.078 & 0.303 & 0.063 \\
\hline $\mathrm{X} 10$ & 0.310 & 0.495 & 0.202 & 0.030 & -0.077 & 0.181 & 0.367 & -0.045 \\
\hline X11 & 0.493 & 0.490 & -0.007 & 0.106 & 0.174 & 0.050 & 0.158 & 0.060 \\
\hline $\mathrm{X} 12$ & 0.645 & 0.062 & 0.016 & 0.195 & -0.100 & 0.147 & 0.077 & 0.078 \\
\hline X13 & 0.604 & 0.394 & 0.041 & -0.074 & 0.131 & 0.169 & 0.018 & 0.174 \\
\hline X14 & 0.718 & 0.259 & 0.110 & -0.028 & 0.103 & 0.013 & 0.071 & 0.135 \\
\hline X15 & 0.750 & 0.134 & 0.161 & 0.086 & 0.221 & -0.167 & 0.099 & 0.014 \\
\hline X16 & 0.632 & 0.161 & 0.100 & 0.257 & 0.165 & 0.060 & 0.159 & -0.228 \\
\hline X17 & 0.576 & 0.131 & 0.125 & 0.244 & 0.154 & 0.037 & 0.360 & -0.302 \\
\hline X18 & 0.208 & 0.184 & 0.100 & 0.090 & 0.218 & 0.145 & 0.655 & -0.026 \\
\hline X19 & 0.084 & 0.236 & 0.092 & 0.108 & 0.034 & 0.124 & 0.636 & 0.207 \\
\hline X20 & 0.170 & 0.001 & 0.212 & -0.225 & 0.153 & 0.452 & -0.019 & 0.452 \\
\hline$X 21$ & 0.053 & 0.105 & 0.119 & 0.104 & 0.076 & 0.795 & 0.086 & 0.038 \\
\hline$X 22$ & 0.029 & 0.021 & 0.116 & 0.160 & 0.132 & 0.764 & 0.156 & -0.013 \\
\hline $\mathrm{X} 23$ & 0.191 & -0.022 & 0.042 & 0.188 & 0.733 & 0.048 & 0.071 & -0.024 \\
\hline X24 & 0.086 & 0.108 & -0.021 & 0.571 & 0.398 & 0.310 & 0.124 & -0.004 \\
\hline $\mathrm{X} 25$ & 0.210 & 0.330 & 0.181 & 0.026 & 0.464 & 0.344 & 0.158 & -0.060 \\
\hline X26 & 0.094 & 0.121 & 0.101 & 0.017 & 0.776 & 0.113 & 0.104 & 0.117 \\
\hline $\mathrm{X} 27$ & 0.111 & 0.289 & 0.528 & 0.206 & 0.354 & 0.046 & 0.015 & 0.116 \\
\hline $\mathrm{X} 28$ & -0.012 & 0.065 & 0.795 & 0.055 & -0.022 & 0.198 & 0.187 & 0.096 \\
\hline X29 & 0.144 & 0.077 & 0.834 & 0.090 & 0.068 & 0.012 & -0.101 & 0.099 \\
\hline X30 & 0.173 & 0.046 & 0.765 & 0.044 & 0.085 & 0.124 & 0.149 & 0.000 \\
\hline X31 & 0.365 & 0.092 & 0.169 & 0.074 & 0.237 & 0.182 & -0.131 & 0.163 \\
\hline
\end{tabular}


Tabel 3. Nilai Loading Faktor Baru

\begin{tabular}{|c|c|c|c|c|c|}
\hline No. & $\begin{array}{l}\text { Faktor } \\
\text { Baru }\end{array}$ & No. Var & Nama Variabel & $\begin{array}{l}\text { Loading } \\
\text { Varians }\end{array}$ & $\%$ Varians \\
\hline \multirow{9}{*}{1} & \multirow{9}{*}{$\begin{array}{c}\text { Kualitas } \\
\text { Layanan } \\
\text { dan } \\
\text { Aplikasi }\end{array}$} & $\mathrm{X} 11$ & Aplikasi mudah untuk digunakan & 0,493 & \multirow{9}{*}{11,846} \\
\hline & & $\mathrm{X} 12$ & Pengiriman lebih cepat dibanding dengan layanan pesan antar & & \\
\hline & & & $\begin{array}{l}\text { konvensional (layanan pesan antar yang disediakan oleh } \\
\text { pihak restoran) }\end{array}$ & 0,645 & \\
\hline & & $\mathrm{X} 13$ & Bisa membayar melalui GoPay atau OVO & 0,604 & \\
\hline & & X14 & $\begin{array}{l}\text { Jumlah mitra pengemudi banyak dan tersebar di berbagai } \\
\text { daerah }\end{array}$ & 0,718 & \\
\hline & & $\mathrm{X} 15$ & Aplikasi aman, terpercaya, dan dapat diakses dimana saja & 0,750 & \\
\hline & & $\mathrm{X} 16$ & Pelayanan memuaskan & 0,632 & \\
\hline & & $\mathrm{X} 17$ & Mitra pengemudi cepat tanggap dan ramah & 0,576 & \\
\hline & & $\mathrm{X} 31$ & $\begin{array}{l}\text { Lebih nyaman memilih menu makan di rumah karena tidak } \\
\text { diburu waktu }\end{array}$ & 0,365 & \\
\hline \multirow{4}{*}{2} & \multirow{4}{*}{ Variasi } & $\mathrm{X} 7$ & Adanya sistem perolehan poin setiap bertransaksi & 0,676 & \multirow{4}{*}{9,649} \\
\hline & & $\mathrm{X} 8$ & $\begin{array}{l}\text { Banyak pilihan mitra pedagang (merchant) } \\
\text { makanan/minuman }\end{array}$ & 0,783 & \\
\hline & & X9 & Banyak pilihan menu makanan/minuman & 0,735 & \\
\hline & & $\mathrm{X} 10$ & $\begin{array}{l}\text { Banyak yang memakai fitur layanan pembelian dan } \\
\text { pengiriman makanan melalui GoFood dan Grabfood }\end{array}$ & 0,495 & \\
\hline \multirow{4}{*}{3} & \multirow{4}{*}{$\begin{array}{l}\text { Gaya } \\
\text { Hidup }\end{array}$} & $\mathrm{X} 27$ & Gofood dan/atau grabfood merupakan suatu kebutuhan & 0,528 & \multirow{4}{*}{8,384} \\
\hline & & $\mathrm{X} 28$ & Menggunakan layanan Gofood/Grabfood karena tren & 0,795 & \\
\hline & & $\mathrm{X} 29$ & Menggunakan layanan Gofood /Grabfood karena gaya hidup & 0,834 & \\
\hline & & X30 & $\begin{array}{l}\text { Menggunakan layanan Gofood /Grabfood karena melihat } \\
\text { iklan (melalui youtube, papan iklan, Instagram, dan lain-lain) }\end{array}$ & 0,765 & \\
\hline \multirow{6}{*}{4} & \multirow{6}{*}{$\begin{array}{c}\text { Efektivitas } \\
\text { dan } \\
\text { Efisiensi }\end{array}$} & $\mathrm{X} 1$ & Efisien & 0,375 & \multirow{6}{*}{7,136} \\
\hline & & $\mathrm{X} 4$ & Lebih murah daripada masak sendiri & 0,647 & \\
\hline & & X5 & $\begin{array}{l}\text { Ongkos kirim setimpal dengan jarak pengiriman dan } \\
\text { pelayanan yang diberikan }\end{array}$ & 0,705 & \\
\hline & & X6 & Banyak promo makanan melalui aplikasi GoFood dan & 0,604 & \\
\hline & & & GrabFood sehingga harga makanan lebih murah & & \\
\hline & & $\mathrm{X} 24$ & $\begin{array}{l}\text { Menghemat ongkos (tidak mengeluarkan biaya untuk bensin } \\
\text { dan kontribusi parkir) }\end{array}$ & 0,571 & \\
\hline \multirow{3}{*}{5} & \multirow{3}{*}{ Kondisional } & $\mathrm{X} 23$ & $\begin{array}{l}\text { Pelayanan tidak mengenal cuaca (tetap mengantar pesanan } \\
\text { ketika hujan deras) }\end{array}$ & 0,733 & \multirow{3}{*}{6,750} \\
\hline & & $\mathrm{X} 25$ & $\begin{array}{l}\text { Adanya fitur untuk melakukan pemesanan ulang (re-order) } \\
\text { menu yang pernah di pesan }\end{array}$ & 0,464 & \\
\hline & & $\mathrm{X} 26$ & $\begin{array}{l}\text { Kondisi yang tidak memungkinkan untuk keluar dari tempat } \\
\text { tinggal, misalnya: cuaca buruk }\end{array}$ & 0,776 & \\
\hline \multirow{2}{*}{6} & \multirow{2}{*}{ Sosial } & $\mathrm{X} 21$ & Rekomendasi teman/rekan kerja & 0,795 & \multirow{2}{*}{6,502} \\
\hline & & $\mathrm{X} 22$ & Rekomendasi keluarga & 0,764 & \\
\hline \multirow{2}{*}{7} & \multirow{2}{*}{ Preferensi } & $\mathrm{X} 18$ & Tidak perlu bingung memilih restoran & 0,655 & \multirow{2}{*}{5,446} \\
\hline & & $\mathrm{X} 19$ & Bosan dengan makanan yang ada di sekitar tempat tinggal & 0,636 & \\
\hline \multirow{3}{*}{8} & \multirow{3}{*}{ Individu } & $\mathrm{X} 2$ & Malas/tidak bisa memasak & 0,703 & \multirow{3}{*}{4,382} \\
\hline & & $\mathrm{X} 3$ & Jadwal aktivitas yang padat & 0,441 & \\
\hline & & $\mathrm{X} 20$ & Tidak memiliki kendaraan & 0,452 & \\
\hline
\end{tabular}

melalui GoPay atau OVO (X13), jumlah mitra pengemudi banyak dan tersebar di berbagai daerah (X14), pelayanan memuaskan (X16), mitra pengemudi cepat tanggap dan ramah (X17), dan lebih nyaman memilih menu makan di rumah karena tidak diburu waktu (X31). Hal ini menunjukkan bahwa keputusan konsumen Surabaya membeli makanan dan minuman melalui aplikasi GoFood dan GrabFood ditentukan oleh kualitas layanan dan aplikasi sebesar 11,846\%.

b. Faktor 2: Variasi

Faktor ini dibentuk oleh variabel-variabel sebagai berikut: adanya sistem perolehan poin setiap bertransaksi (X7), banyak pilihan mitra pedagang/merchant makanan atau minuman (X8), banyak pilihan menu makanan atau minuman (X9) 
dan banyak yang memakai fitur layanan pembelian dan pengiriman makanan melalui GoFood dan GrabFood (X10). Hal ini menunjukkan bahwa keputusan konsumen Surabaya dalam pembelian makanan dan minuman melalui aplikasi GoFood dan GrabFood ditentukan oleh variaso sebesar $9,649 \%$.

c. Faktor 3: Gaya Hidup

Faktor ini dibentuk oleh variabel-variabel sebagai berikut: GoFood dan/atau GrabFood merupakan suatu kebutuhan (X27), menggunakan layanan GoFood atau GrabFood karena tren (X28), menggunakan GoFood atau GrabFood karena gaya hidup (X29) dan menggunakan layanan GoFood atau GrabFood karena melihat iklan (melalui youtube, papan iklan, instagram dan lain-lain) (X30). Kondisi ini menunjukkan bahwa keputusan konsumen Surabaya dalam pembelian makanan dan minuman melalui aplikasi GoFood dan GrabFood ditentukan oleh gaya hidup sebesar 8,384\%.

d. Faktor 4: Efektivitas dan Efisiensi

Faktor ini dibentuk oleh variabel-variabel sebagai berikut: efisien (X1), lebih murah daripada masak sendiri (X4), ongkos kirim setimpal dengan jarak pengiriman dan pelayanan yang diberikan (X5), banyak promo makanan melalui aplikasi GoFood dan GrabFood sehingga harga makanan lebih murah (X6) dan menghemat ongkos (tidak mengeluarkan biaya untuk bensin dan kontribusi parkir) (X24). Hal ini menunjukkan bahwa keputusan konsumen Surabaya dalam pembelian makanan dan minuman melalui aplikasi GoFood dan GrabFood ditentukan oleh efektivitas dan efisiensi sebesar 7,136\%.

e. Faktor 5: Kondisional

Faktor ini dibentuk oleh variabel-variabel sebagai berikut: pelayanan tidak mengenal cuaca (tetap mengantar pesanan ketika hujan deras) (X23), adanya fitur untuk melakukan pemesanan ulang/ re-order menu yang pernah dipesan (X25) dan kondisi yang tidak memungkinkan untuk keluar dari tempat tinggal (misalnya cuaca buruk) (X26). Hal ini menunjukkan bahwa keputusan konsumen Surabaya dalam pembelian makanan dan minuman melalui aplikasi GoFood dan GrabFood ditentukan oleh kondisional sebesar 6,750\%.

f. Faktor 6: Sosial

Faktor ini dibentuk oleh variabel-variabel sebagai berikut: rekomendasi teman/rekan kerja (X21) dan rekomendasi keluarga (X22). Kondisi ini menunjukkan bahwa keputusan konsumen Surabaya dalam pembelian makanan dan minuman melalui aplikasi GoFood dan GrabFood ditentukan oleh sosial sebesar 6,502\%.

\section{g. Faktor 7: Preferensi}

Faktor ini dibentuk oleh variabel-variabel sebagai berikut: tidak perlu bingung memilih restoran (X18) dan bosan dengan makanan yang ada di sekitar tempat tinggal (X19). Dengan demikian keputusan konsumen Surabaya dalam pembelian makanan dan minuman melalui aplikasi GoFood dan GrabFood ditentukan oleh preferensi sebesar $5,446 \%$.

h. Faktor 8: Individu

Faktor ini dibentuk oleh variabel-variabel sebagai berikut: malas/tidak bisa memasak(X2), jadwal aktivitas yang padat (X3), dan tidak memiliki kendaraan (X20). Dengan demikian keputusan konsumen Surabaya dalam pembelian makanan dan minuman melalui aplikasi GoFood dan GrabFood ditentukan oleh individu sebesar 4,382\%.

\section{PEMBAHASAN}

Berdasarkan analisa deskriptif, diketahui bahwa konsumen Surabaya memilih melakukan pembelian makanan melalui aplikasi GoFood dan/atau GrabFood karena banyak promo yang diadakan oleh pihak GoFood dan GrabFood dengan nilai mean 4,42 yang berarti sangat setuju. Hal ini selaras dengan analisa profil responden. Pada umumnya, pelajar/mahasiswa memiliki uang saku per bulan yang terbatas, sehingga membuat para responden yang berada di usia tersebut senang mencari promo atau diskon untuk menghemat pengeluaran. Sedangkan konsumen Surabaya tidak setuju dalam menggunakan layanan GoFood/Grab Food karena tren dengan nilai mean 2,56. Saat ini masyarakat Surabaya menilai bahwa layanan GoFood/ GrabFood dapat membuat pekerjaan menjadi efisien. Konsumen Surabaya banyak yang memilih layanan GoFood dan GrabFood karena menganggap layanan tersebut sebagai suatu gaya hidup dan kebutuhan, meskipun tidak sepenuhnya mendorong konsumen untuk membeli melalui aplikasi tersebut. Hal ini dapat dilihat pada variabel X29 dan X27 menunjukkan nilai mean 2,66 dan 3,29 yang masuk kategori cukup setuju. Hal ini menujukkan bahwa responden dalam membeli makanan tidak mengandalkan aplikasi online saja karena responden masih dapat membeli makanan dan minuman langsung di restoran yang diinginkan.

Berdasarkan analisa faktor, ada 8 faktor baru yang terbentuk dari 31 variabel yang ada, yaitu kualitas layanan dan aplikasi, variasi, gaya hidup, efektivitas dan efisiensi, kondisional, sosial, preferensi dan individu. Faktor yang paling mendorong konsumen Surabaya dalam pembelian makanan dan minuman melalui GoFood dan GrabFood adalah faktor kualitas 
layanan dan aplikasi sebesar $11,846 \%$. Hal ini didorong dengan penggunaan aplikasi yang mudah, layanan yang baik, bisa membayar melalui dompet digital dan jumlah pengemudi yang banyak. Dapat diketahui pula bahwa ada beberapa faktor yang memiliki kesamaan dengan penelitian yang dilakukan oleh Dewi, Suthanaya, dan Sujadi (2019) pada penelitian tersebut juga terbentuk faktor kualitas layanan dan aplikasi, gaya hidup dan individu. Sedangkan, beberapa faktor lainnya memiliki kesamaan dengan penelitian yang dilakukan oleh Santoso dan Prayitno (2011), yaitu: faktor efektivitas dan efisiensi, faktor variasi, faktor gaya hidup dan faktor kondisional.

Menurut pengamatan yang dilakukan oleh penulis, tidak semua faktor yang terbentuk pada penelitian Dewi, Suthanaya, dan Sujadi (2019) serta Santoso dan Prayitno (2011) relevan dengan keadaan konsumen yang ada di Surabaya saat ini. Hal ini disebabkan adanya perubahan perilaku konsumen sebagai sesuatu yang dinamis. Penelitian yang dilakukan oleh Dewi, Suthanaya, dan Sujadi (2019) tidak sepenuhnya relevan dengan realita yang terjadi pada konsumen Surabaya karena adanya perbedaan budaya, serta penelitian tersebut lebih mengarah ke penggunaan layanan aplikasi Gojek/Grab secara umum. Sedangkan penelitian yang dilakukan oleh Santoso dan Praytino lebih mengarah pada penggunaan 2 website yang menyediakan layanan pesan antar online. Penelitian tersebut sudah dilakukan beberapa tahun silam, di mana kondisi dan perilaku konsumen sudah mulai berubah.

Faktor pertama, kualitas layanan dan aplikasi. Faktor ini merupakan faktor yang menyangkut bagaimana performa aplikasi yang dimiliki oleh perusahaan Gojek dan Grab. Selain itu, faktor ini juga menjelaskan jika pelayanan yang diberikan oleh mitra pengemudi baik, maka akan mendorong responden untuk menggunakan layanan GoFood dan GrabFood. Hal ini sesuai dengan penelitian Dewi, Suthanaya, dan Sujadi (2019) bahwa kualitas layanan dan aplikasi merupakan faktor yang mempunyai kontribusi paling besar.

Faktor kedua, variasi. Faktor ini tidak dapat dipungkiri jika banyak pilihan mitra pedagang/merchant yang tergabung dalam GoFood dan GrabFood sehingga responden memiliki banyak pilihan menu atau mitra pedagang yang dapat dipilih. Disamping itu, responden menyukai layanan pesan antar makanan secara online, karena responden mendapat poin yang bisa menjadi keuntungan tambahan bagi responden. Faktor ini sesuai dengan faktor variasi dalam penelitian Santoso dan Prayitno (2011).

Faktor ketiga, gaya hidup. Menurut pengamatan penulis, fenomena yang terjadi saat ini adalah layanan GoFood dan GrabFood telah menjadi sebagian dari kebutuhan responden. Meskipun tidak sepenuhnya, GoFood dan GrabFood telah menjadi gaya hidup baru di lingkungan Surabaya. Faktor ini sesuai dengan faktor gaya hidup dalam penelitian Santoso dan Prayitno (2011) serta penelitian yang dilakukan oleh Dewi, Suthanaya, dan Sujadi (2019).

Faktor keempat, efektivitas dan efisiensi. Faktor ini tidak dapat dipungkiri bahwa layanan GoFood dan GrabFood merupakan layanan yang efisien dan sesuai dengan kondisi yang terjadi saat ini. Dampak yang dapat dilihat, banyak gerai makanan dan minuman di Surabaya yang dipadati oleh kerumunan pengemudi layanan aplikasi ini. Diskon atau promo yang menarik juga banyak diberikan sehingga konsumen Surabaya tertarik untuk menggunakan layanan GoFood dan GrabFood karena dinilai efisien. Faktor ini sesuai dengan faktor efektivitas dan efisiensi dalam penelitian Santoso dan Prayitno (2011).

Faktor kelima, kondisional. Banyak kondisi yang membuat responden malas keluar rumah untuk membeli makanan. Salah satu kondisi yang tidak dapat diprediksi dan dihindari adalah cuaca buruk, misalnya hujan angin. Dalam kondisi tersebut, banyak responden yang memanfaatkan layanan GoFood dan Grab Food. Di sisi lain, pada kondisi tersebut banyak mitra pengemudi yang bersedia untuk mengantar pesanan konsumen. Faktor ini sesuai dengan faktor kondisional dalam penelitian Santoso dan Prayitno (2011).

Faktor keenam, sosial. Mayoritas responden berumur 17-25 tahun, dapat dikatakan bahwa mayoritas responden adalah remaja. Karakteristik remaja dalam mengambil keputusan masih sangat dipengaruhi oleh lingkungan sekitar, terutama keluarga dan teman. Hal ini membuat responden cenderung mendengar apa yang direkomendasikan oleh keluarga atau lingkungan sekitarnya. Faktor ini sesusai dengan faktor yang terbentuk pada penelitian Dewi, Suthanaya, dan Sujadi (2019).

Faktor ketujuh, preferensi. Menurut pengamatan dan pengalaman yang dialami penulis, seiring dengan berjalannya waktu, seringkali timbul rasa bosan dengan makanan yang tersedia di sekitar tempat tinggal konsumen. Hal ini mendorong keinginan untuk membeli makanan yang berada di kawasan lainnya secara online. Disamping itu, masing-masing konsumen memiliki preferensi menu makanan yang berbeda sehingga masing-masing individu dapat memilih menu makanan yang dikehendaki dengan lebih leluasa. Faktor ini merupakan faktor baru yang ditemukan pada penelitian ini.

Faktor kedelapan, individu. Sebagian besar responden adalah mahasiswa. Mahasiswa/pelajar biasanya cenderung memiliki aktivitas sedang sampai tinggi, tidak punya waktu karena disibukkan dengan aktivitas perkuliahan dan mayoritas merupakan anak rantau yang biasanya tidak memiliki kendaraan di 
tempat tinggal saat ini. Faktor ini sesusai dengan faktor yang ditemukan pada penelitian Dewi, Suthanaya, dan Sujadi (2019).

\section{SIMPULAN DAN SARAN}

\section{Kesimpulan}

1. Pada penelitian ini terbentuk 8 faktor baru yang relevan dengan keadaan saat ini pada konsumen di Surabaya. Faktor-faktor tersebut adalah kualitas layanan dan aplikasi (11,846\%), variasi $(9,649 \%)$, gaya hidup $(8,384 \%)$, efektivitas dan efiesiensi $(7,136 \%)$, kondisional $(6,750 \%)$, sosial $(6,502 \%)$, preferensi $(5,446 \%)$ dan individu (4,382\%).

2. Faktor kualitas layanan dan aplikasi merupakan yang faktor yang paling berkontribusi mendorong konsumen Surabaya membeli makanan dan minuman melalui aplikasi GoFood dan GrabFood.

\section{Saran}

1. Merujuk pada temuan penelitian ini yaitu faktor yang paling berkontribusi mendorong konsumen Surabaya membeli makanan dan minuman melalui aplikasi GoFood dan GrabFood adalah kualitas layanan dan aplikasi. Oleh karena itu, bagi pihak Gojek dan Grab dapat lebih mengembangkan aplikasi yang baru lagi agar konsumen Surabaya dapat menggunakan aplikasi lebih mudah.

2. Bagi penelitian selanjutnya diharapkan dapat meneliti lebih jauh tentang faktor kualitas layanan dan aplikasi, mengingat seiring berjalannya waktu perilaku konsumen Surabaya dalam membeli makanan dan minuman secara online dapat berubah. Selain itu dapat juga dikembangkan pada kota-kota lain di Indonesia.

\section{DAFTAR REFERENSI}

Amirullah. (2002). Perilaku konsumen. Yogyakarta: Graha Ilmu.

Dewi, L. K. C., Suthanaya, I. P. B., \& Sujadi, D. (2019). Faktor Faktor yang dipertimbangkan Konsumen dalam menggunakan Gojek Online di Kabupaten Badung. Jurnal Ilmiah Manajemen \& Akuntansi, 25 (1), 84-98.

Ghozali, I. (2012). Aplikasi analisis multivariate dengan program IBM SPSS 20 (6 th ed.). Semarang: Badan Penerbit Universitas Diponegoro.
Hair, J.F., Black, W. C., Babin, B. J., \& Anderson, R. E. (2010). Multivariate data analysis: A global perspective. New Jersey: Pearson Prentice Hall.

Harahap, D. A., \& Amanah, D. (2018). Perilaku belanja online di Indonesia. Jurnal Riset Manajemen Sains Indonesia, 9 (2), 193-213. http://doi. org/10.21009/JRMSI.

Jogiyanto, H. M. (2008). Metodologi penelitian sistem informasi. Yogyakarta: ANDI.

Kim, D. J., Ferrin, D. L., \& Rao, H. R. (2008). A trustbased consumer decision-making model in electronic commerce: The role of trust, perceived risk, and their antecedents. Science Direct, 44 (2), 544-564. https://doi.org/10.1016/j.dss.2007.07.001

Kotler, P \& Armstrong, G. (2016). Principles of marketing (16th Edition). Boston: Pearson.

Kotler, P \& Keller, K. L. (2006). Marketing management (12th Edition). Upper Saddle River, NJ: Pearson Education.

Lupiyoadi, R. \& Hamdani, A. (2006). Manajemen pemasaran jasa (edisi 2). Jakarta: Salemba Empat.

Martono, N. (2016). Metode penelitian kuantitatif: Analisis isi dan analisis data sekunder (edisi revisi 2, cetakan 5). Jakarta: Rajawali Pers.

Mowen, J. C \& Minor, M. (2001). Consumer behavior: A framework. New Jersey: Prentice Hall.

Peter, J.P \& Olson, J.C (2008). Consumer behavior and marketing strategy. Singapore: McGraw Hill.

Santoso, A., \& Prayitno, R.D. (2011). Faktor-faktor yang mendorong konsumen Surabaya dalam melakukan pembelian makanan secara online. (TA NO. 33010296/MAN/2011). Unpublished undergraduate thesis, Universitas Kristen Petra.

Suhari, Y. (2008). Keputusan Membeli Secara Online dan Faktor-Faktor yang Mempengaruhinya. Jurnal Teknologi Informasi DINAMIK, 13 (2), 140146.

Sujarweni, V.W. \& Endrayanto, P. (2012). Statistika untuk penelitian. Yogyakarta: Graha Ilmu.

Veronika, S. (2013). Motivation of online buyer behavior. Journal of Competitiveness, 5(3), 1430. http://doi.org/10.7441/joc.2013.03.02

Wilson, R. M. S. \& Giligan, C. (2005). Strategic marketing management: Planning implementation \& control. Italia: Elsevier.

Zeithaml, V. A., Bitner, M. J., \& Gremier, D. D. (2009). Services marketing: Integrating customer focus across the firm (5 $5^{\text {th }}$ edition). Singapore: McGraw Hill. 